\title{
A TEORIA DA PONDERAÇÃO DE ALEXY E O DEPÓSITO NA PENHORA DE PERCENTUAL DO FATURAMENTO: UMA PROPOSTA DE SUPERAÇÃO DA SÚMULA 319 DO STJ
}

\begin{abstract}
ALEXY'S WEIGHT FORMULA AND DEPOSIT ON BILLING PERCENTAGE OF ATTACHMENT: A PROPOSAL FOR OVERCOMING THE STJ PRECEDENT 319
\end{abstract}

\author{
${ }^{1}$ Thiago Moreira Da Silva \\ ${ }^{2}$ Gustavo Leite Caribé Checcucci
}

\section{RESUMO}

Este trabalho possui por finalidade demonstrar como a Teoria da Ponderação de Alexy poderá contribuir para a superação do entendimento cristalizado na Súmula 319 do STJ, ao validar, através de um discurso prático racional, a decisão judicial que impõe ao administrador da empresa executada, seja ele sócio ou não, a assunção do depósito da penhora de percentual de faturamento. Para a consecução desse objetivo, inicialmente, por meio do método teórico-descritivo, realizou-se a exposição crítica das razões de decidir dos precedentes fundantes da súmula em comento em confronto com os princípios norteadores do processo e da atividade jurisdicional no constitucionalismo contemporâneo e com preceitos doutrinários e julgados do próprio Superior Tribunal de Justiça e do Supremo Tribunal Federal. Na sequência, através do método dedutivo, defendeu-se a necessidade de redimensionamento do princípio da legalidade estrita diante da atual ordem constitucional, em que princípios assumem a qualidade de norma jurídica, sendo eles próprios fontes primárias de obrigações e deveres. Como fundamento principiológico desse dever, foi invocado o princípio da atipicidade dos meios executivos, como corolário do direito fundamental a uma tutela efetiva e adequada e da cláusula constitucional da vedação do non liquet, bem como da cooperação e da boa-fé objetiva processual. A título de conclusão, como forma de evitar o chamado decisionismo e validar de forma racional a decisão judicial de intervenção no direito fundamental do administrador da empresa executada, realizou-se a exposição analítica da Teoria da Ponderação de Alexy em cotejo com as particularidades do caso em estudo.

Palavras-chave: Depósito, Penhora de faturamento, Direitos fundamentais, Colisão, Ponderação

\begin{abstract}
This work has intended to demonstrate how the Alexy's Weight Formula can contribute to overcome the crystallized understanding of the STJ Precedent 319, validating it, through a rational practical speech, a juridical decision requiring the company administrator, being a formal partner or not, an assumption of the deposit on billing percentage of attachement. To achieve this objective, initially, through a theoretical and descriptive method, it was performed a critical exposition of the reasons to decide a previous founding of the higher rule
\end{abstract}

1 Mestrando em Direito pela Universidade Federal de Sergipe. Procurador da Fazenda Nacional. Professor de Direito Processual Civil da Faculdade de Administração e Negócios de Sergipe. Faculdade de Administração e Negócios de Sergipe - FANESE, Aracaju - SE. Brasil - E-mail:thgmoreira80@gmail.com

2 Mestrando em Direito na Universidade Federal de Sergipe.dvogado e professor titular de Direito Processual Civil e Administrativo da Faculdade Regional da Bahia. Faculdade Regional da Bahia - FARB, Bahia. Brasil -

E-mail: gustavocheccucci@hotmail.com

Teorias do Direito e Realismo Jurídico| e-ISSN: 2525-9601| Minas Gerais | v. 1 | n. 2 | p. 122- 154| Jul/Dez. 2015. 
under discussion with the guide principles of the process and the juridical activity of the contemporary constitutionalism with doctrinal precepts and the Superior and Federal Supreme court's own judgments. Following through the deductive method, it was defended the need to re-size the principle of the strict legality at the current constitutional order, in which principles become a rule of the law, having them as the primary source of obligations and duties. As the principle foundation of this duty, it was called the atypical principle of the executive, as a corollary of fundamental rights to an effective and adequate protection and constitutional forbidden clause the non liquet as well as the cooperation and procedural faithful objective. As the conclusion, in order to avoid decisionism and validate in a rational manner the ruling intervention of the executed business administrator fundamental rights, it was performed the analytical exposure of Alexy's Weight Formula in comparison with the studied particularities of the the case.

Keywords/Palabras-claves/Mots-clés: Deposit, Billing attachment, Fundamental rights, Conflict, Weighting 


\section{INTRODUÇÃO}

O objetivo deste trabalho é demonstrar como a Teoria da Ponderação de Alexy poderá contribuir, no que tange à penhora do percentual de faturamento, para a superação do entendimento da Súmula 319 do Superior Tribunal de Justiça (STJ) - “o encargo de depositário de bens penhorados pode ser expressamente recusado" (BRASIL, 2005b), ao fundamentar a validade da medida judicial que impõe, com base no poder geral de efetivação, a assunção do depósito ao sócio-administrador da empresa executada.

Por ser medida excepcional, conforme entendimento pacífico do Superior Tribunal de Justiça, e considerando a ineficiência das medidas executivas remanescentes previstas no art. 655 do Código de Processo Civil (CPC) (BRASIL, 1973), é alto o potencial de frustração da execução quando a penhora de percentual de faturamento não se concretiza.

A Súmula 319 do STJ instituiu um verdadeiro direito potestativo em favor dos devedores ao permitir a recusa, de forma imotivada, da assunção do encargo de depositário, sem quaisquer ressalvas quanto à possibilidade de satisfação da execução por outra via.

Pretende-se, desta forma, analisar se os fundamentos dos precedentes invocados como razão de decidir são compatíveis com os princípios que conformam a atividade jurisdicional no constitucionalismo contemporâneo, sob o paradigma do Estado Democrático de Direito, notadamente em face do princípio constitucional da inafastabilidade da apreciação pelo Poder Judiciário, previsto no art. 5², inciso XXXV, da Constituição Federal de 1988 (CF/88) (BRASIL, 1988), que garante, no ordenamento jurídico brasileiro, o direito fundamental a uma prestação jurisdicional efetiva e adequada.

Além de evidenciar a insubsistência das razões fundantes do enunciado sumular em debate, buscar-se-á demonstrar, com base na Teoria da Ponderação de Alexy, que o principal fundamento invocado pela Súmula 319 do STJ - proteção da autonomia privada pelo princípio da legalidade estrita - não subsiste ao crivo dos três princípios parciais do princípio da proporcionalidade: adequação, necessidade e proporcionalidade em sentido restrito.

Busca-se, desta forma, justificar de forma racional, por meio da utilização da Teoria da Ponderação de Alexy, a intervenção judicial em um direito fundamental, revelada pela imposição ao administrador da empresa executada do encargo de depositário da penhora de percentual de faturamento, sem recair em um decisionismo, e, com isso, contribuir para a superação do entendimento consagrado na Súmula 319 do STJ.

A discussão cingir-se-á, contudo, ao depósito na penhora de percentual de faturamento, tendo em vista a existência de circunstâncias específicas deste instituto. 
Para isso, em um primeiro momento, através do método teórico-descritivo, serão realizadas a exposição da problemática da recusa imotivada do encargo de depositário pelo administrador da empresa executada e a análise crítica dos precedentes fundantes do entendimento sumular em comento, em cotejo com posicionamentos jurisprudenciais e doutrinários prevalecentes na atual processualística.

$\mathrm{Na}$ segunda parte do trabalho, através do método dedutivo, serão analisadas as premissas gerais da fundamentação principiológica, bem como os princípios específicos da atipicidade dos meios executivos como corolário do direito fundamental a uma tutela efetiva e adequada, da cooperação e boa-fé objetiva processual, em cotejo com a Teoria da Ponderação de Alexy, para fundamentar, de forma argumentativa e racional, a decisão judicial que impõe ao administrador da empresa executada a assunção do encargo em destaque.

A pesquisa, diante de seu caráter qualitativo, valeu-se da leitura primária de material doutrinário, legal e jurisprudencial pertinente ao objeto do presente estudo.

\section{DA PROBLEMÁTICA DA RECUSA IMOTIVADA DO DEPÓSITO DA PENHORA DE PERCENTUAL DE FATURAMENTO PELO REPRESENTANTE LEGAL DA EMPRESA EXECUTADA}

A penhora de percentual de faturamento restou positivada no ordenamento jurídico pátrio por meio da Lei $\mathrm{n}^{\circ}$ 11.382/2006 (BRASIL, 2006), que deu nova redação ao art. 655, VII, do CPC, e introduziu nesse diploma o art. 655-A, em cujo $\S 3^{\circ}$ estão reguladas a forma de nomeação do depositário e as atribuições desse encargo.

É posição dominante nos tribunais que a penhora de percentual de faturamento é medida excepcional, somente adotada quando frustrados diversos outros meios executivos, a exemplo do que restou decidido pelo Superior Tribunal de Justiça nos julgamentos dos Agravos Regimentais nos Recursos Especiais (AgRg no REsp) de nº 1.313.904 (BRASIL, 2012a) e 1.320.996 (BRASIL, 2012b).

A própria posição do inciso VII no art. 655 do CPC (BRASIL, 1973) indica sua ordem de preferência em relação aos outros bens penhoráveis, de modo que, para que seja formulado um pedido de penhora de percentual de faturamento, já restaram esgotadas as tentativas de constrição dos seguintes bens: dinheiro, em espécie ou em depósito ou aplicação em instituição financeira, veículos de via terrestre, bens móveis em geral, bens imóveis, navios e aeronaves, ações e quotas de sociedades empresárias. 
Pela redação do art. 655 do CPC, somente não precedem a penhora de percentual de faturamento os bens e direitos a seguir discriminados: pedras e metais preciosos, títulos da dívida pública da União, Estados e Distrito Federal com cotação em mercado, títulos e valores mobiliários com cotação em mercado e outros direitos, como marcas e patentes, por exemplo.

Sem olvidar dos óbices práticos quanto à avaliação, tais bens dificilmente despertam interesse no mercado, além de ser rara a propriedade de referidos direitos e coisas por parte de uma empresa que figura no polo passivo de uma execução, de modo que, quando se mostram presentes os pressupostos fáticos e jurídicos para uma penhora de percentual de faturamento, se essa não se concretiza, muito possivelmente a execução restará frustrada.

Em que pese a discussão doutrinária acerca da natureza do depósito, se integra a penhora (BRAGA et al, 2009, p. 585) ou é apenas seu complemento (ARENHART; MARINONI, 2008, p. 283), certo é que, sem a indicação de um depositário, muitas vezes a constrição sequer é deferida; e quando isso ocorre, a ausência de um administrador da constrição esvazia o instituto.

Justamente tendo em conta esse panorama fático-jurídico que os administradores levam em consideração para recusar o encargo do depósito da penhora em debate, em uma clara posição de indiferença para com a atividade jurisdicional e o processo.

O assunto possui atualidade, uma vez que nem mesmo o novo Código de Processo Civil, instituído pela Lei $\mathrm{n}^{\mathrm{o}} 13.105 / 2015$ (BRASIL, 2015), impõe ao devedor, de forma expressa, o ônus de assumir o referido encargo.

Com efeito, o art. 853 do novo CPC praticamente repete a redação do art. 655 do CPC vigente, mas incrementa a excepcionalidade do instituto, relegando-o ao inciso $\mathrm{X}$, observada a ordem de gradação estipulada pelo caput.

É certo que o $\S 1^{\circ}$ do art. 853 do novo CPC positiva o entendimento jurisprudencial de que a ordem estabelecida pelo caput poderá ser afastada no caso concreto, diante de certas condições específicas. Contudo, tendo em conta o histórico da jurisprudência sobre o tema, que já impunha o caráter de excepcionalidade à penhora de percentual de faturamento antes mesmo de sua introdução no CPC em vigor por meio da Lei $n^{\circ} 11.382 / 2006$, muito provavelmente os tribunais continuarão a deferir a aplicação do instituto somente nas hipóteses de esgotamento de outros meios executivos.

Além da previsão genérica referida acima, a penhora de percentual de faturamento recebeu tratamento singelo do legislador reformador, sendo regulada por meio de um único artigo (art. 866 do novo CPC), que traça as linhas gerais do instituto, mas sem descer a minúcias.Destaque-se, ainda, que o $\S 3^{\circ}$ do art. 866 do novo CPC prevê que serão aplicáveis, 
no que couber, as regras previstas para a penhora de frutos e rendimentos de coisa móvel e imóvel, regulada nos arts. 867 a 869 do mesmo diploma legal.

O art. 869 do referido diploma, por sua vez, prevê que tanto o credor quanto o devedor podem ser nomeados como administrador-depositário; contudo, quando não houver acordo, tal encargo poderá recair sobre profissional habilitado indicado pelo juízo.

Como se vê, o novel CPC não impõe ao devedor qualquer ônus diante da recusa imotivada para a assunção do encargo de depositário da penhora de percentual de faturamento, de modo que a ratio da Súmula 319 do STJ ainda poderá ser livremente invocada por aqueles que pretendem frustrar a prestação jurisdicional, fiando-se na certeza de que raramente o credor ou o juízo dispõem de pessoas habilitadas para exercer tal múnus.

Com fito de alcançar o objetivo do presente trabalho, a partir do próximo tópico, passase à exposição e análise dos fundamentos dos precedentes que restaram consolidados na súmula em debate. 


\section{DA ANÁLISE CRÍTICA DOS PRECEDENTES QUE ENSEJARAM A SÚMULA 319 DO STJ}

A Súmula 319 do STJ foi aprovada por sua Corte Especial no ano de 2005 e assim dispõe: "o encargo de depositário de bens penhorados pode ser expressamente recusado" (BRASIL, 2005b).

Da análise dos precedentes que deram origem ao referido entendimento sumulado, consoante informação disponível no sítio eletrônico do $\mathrm{STJ}^{1}$, as razões de decidir podem ser assim categorizadas: a) impossibilidade da prisão civil na hipótese de recusa expressa do depositário em assumir o encargo, invocada nos julgados do Recurso Especial (Resp) 161.068 (BRASIL, 1998), Habeas Corpus (HC) 28.152 (BRASIL, 2003a), Recurso Ordinário em Habeas Corpus (RHC) 14.647 (BRASIL, 2003b), HC 31.733 (BRASIL, 2004b), HC 20.789 (BRASIL, 2004a), RHC 15.891 (BRASIL, 2004e) e HC 34.229 (BRASIL, 2004c); b) o depósito judicial teria natureza de negócio jurídico dependente da aceitação do devedor, única razão fundante do Agravo Regimental no Agravo de Instrumento (AgReg no Ag) 199.378 (BRASIL, 1999a); e c) o princípio da estrita legalidade, segundo o qual "ninguém será obrigado a fazer ou deixar de fazer alguma coisa senão em virtude de lei” (art. 5º, II, da CF/88), um dos pilares do julgado do Resp $161.068^{2}$ (BRASIL, 1998) e principal razão de decidir do Resp 214.631 (BRASIL, 1999b), Resp 276.886 (BRASIL, 2001), Resp 263.910 (BRASIL, 2004d) e Resp 505.942 (BRASIL, 2005a).

\footnotetext{
1 Disponível em: <http://www.stj.jus.br/SCON/sumulas/doc.jsp?livre=\%40docn\&\&b=SUMU\&p=true\&t=\&l=10\&i=223>. Acesso em: 15 jul. 2015.
} 
Dentre os julgados que cuidavam da liberdade individual do depositário em face da possibilidade da prisão civil, destaca-se o Resp 161.068, em que a preocupação com a liberdade individual do depositário revelou-se patente no voto do relator, Ministro Adhemar $\mathrm{Maciel}^{3}$, cujo trecho segue transcrito abaixo:

A recorrente especial diz que o acórdão violou o art. 600 do CPC. Laconicamente - o que não se aceita em recurso -, não aponta qual o dispositivo, já que o art. 600 conta quatro incisos. Aliás, não teria mesmo como apontar, pois não existe. Fala, também, que o aresto contrariou o art.

1.282 do CC. Ora, Senhor, Presidente, em matéria de liberdade individual não se pode, data venia, agir por inferência, per tabelam. Se a lei não obriga expressamente, não se pode fazer elucubrações e maquinações para contorná-la. Os direitos e as garantias fundamentais, como se percebe, correriam sério risco se se pudesse fazer tais contornos (BRASIL, 1998).

De igual modo ocorreu nos demais julgados categorizados no primeiro grupo - HC 28.152, RHC 14.647, HC 31.733, HC 20.789, RHC 15.891 e HC 34.229 -, em que a liberdade individual do devedor prevaleceu nas situações fáticas em que não houve expressa anuência da assunção do encargo.

Observe-se que em nenhum desses julgados houve análise percuciente acerca da obrigação de assumir o depósito ou não.

Não obstante, tais precedentes perderam sua força persuasiva.

De fato, é suficiente registrar que, quando da aprovação da súmula em debate, no ano de 2005, o Supremo Tribunal Federal (STF) ainda não tinha se posicionado pela inconstitucionalidade da prisão do depositário infiel, quando, no julgamento do HC 90450 (BRASIL, 2009a), conferiu status constitucional à Convenção Americana de Direitos Humanos (art. $7^{\circ}$, n. 7), incorporada pelo Decreto $\mathrm{n}^{\mathrm{o}}$ 678, de 6 de novembro de 1992 (BRASIL, 1992), e concluiu pela insubsistência de qualquer prisão advinda de depósito, necessário ou não, tendo em conta que a única prisão civil admitida em nosso ordenamento é a do inadimplente inescusável de pensão alimentícia.

\footnotetext{
2 Como demonstrado acima, o referido julgado assentou-se em duas razões de decidir, quais sejam, a impossibilidade de prisão civil do depositário infiel e o princípio da legalidade estrita.

3 O outro fundamento de sustentação do julgado, como se deixa transparecer no trecho citado acima, foi a ausência de lei específica prevendo a assunção desse ônus, o que atrairia a incidência do art. $5^{\circ}$, II, da CF, fundamento esse que será analisado adiante.
} 
Referido entendimento, não se olvide, restou cristalizado na Súmula Vinculante $\mathrm{n}^{\circ} 25$ - "É ilícita a prisão civil de depositário infiel, qualquer que seja a modalidade do depósito" (BRASIL, 2009b) e na Súmula do STJ no 419 - "Descabe a prisão civil do depositário judicial infiel" - (BRASIL, 2010b).

Pode-se concluir, portanto, que a ratio que sustenta os precedentes ora em destaque já não pode mais ser invocada diante da decretação da inconstitucionalidade da prisão de depositário infiel, justamente pelo fato de que o objeto principal dos referidos julgados era a liberdade de locomoção dos depositários, que atualmente não pode mais ser ameaçada por conta da assunção do encargo.

Ainda nesse sentido, saliente-se que o habeas corpus não é o foro adequado para a discussão exauriente de questões cíveis, vez que possui cognição limitada ao cerceamento do direito fundamental de ir e vir, conforme já reconhecido pelo STJ em diversas ocasiões, a exemplo dos Habeas Corpus $\mathrm{n}^{\circ} 54.575$ (BRASIL, 2007) e $\mathrm{n}^{\circ} 145.747$ (BRASIL, 2010a).

A segunda razão de decidir, na verdade, foi invocada em apenas um precedente (AgReg no Ag 199.378), que utilizou o ensinamento de Pontes de Miranda segundo o qual o depósito teria natureza de negócio jurídico, cuja aceitação dependeria da vontade do devedor.

A fundamentação constante do voto condutor do referido julgado, de lavra do Min. Ilson Naves, resume-se a um único parágrafo, assim vazado:

\footnotetext{
Não entendi a alegação de que se trata de interpretação "quiçá" anacrônica. Por quê? Será pela circunstância de, na origem, ter-se louvado em lição de Pontes? Sei lá, o que sei e o que afirmo é que não há, na espécie em comento, ofensa a texto de lei federal. "Pode o exequente," - bem disse o Tribunal estadual - "se tiver motivo lícito, impedir que o encargo seja entregue ao devedor, mas não lhe é permitido constrangê-lo à assunção". Nesse aspecto, não se ofendeu o art. 666. Veja-se a lição de Pontes, em comentários a essa disposição: "A Lei considera o depósito judicial em mão do devedor como negócio em que a declaração de vontade do Estado é dependente de aceitação do devedor e do exequente". (BRASIL, 1999a)
}

Em que pese a autoridade do posicionamento do ilustre jurista, a figura do depósito judicial como negócio privado não se coaduna com o entendimento secular no sentido da natureza pública da relação jurídica processual.

Com a obra Teoria dos pressupostos processuais e das exceções dilatórias, publicada em 1868, Oskar von Bülow firmou o entendimento, até hoje consagrado entre os processualistas, de que o processo possui a natureza jurídica de uma relação jurídica, a qual, diante do monopólio da atividade jurisdicional pelo Estado, é intrinsecamente de natureza publicista (CINTRA; DINAMARCO; GRINOVER, 2012, p. 312). 
Na lição de Dinamarco (2013, p. 60), “o caráter público do processo hoje prepondera acentuadamente, favorecido pelo vento dos princípios constitucionais do Estado social intervencionista e pelo apuro técnico das instituições processuais".

Como toda relação jurídica, as partes nela envolvidas assumem diversas posições, sejam elas ativas ou passivas, representadas por deveres, direitos, faculdades, sujeições e ônus (CINTRA; DINAMARCO; GRINOVER, 2012, p. 314-315).

Para o réu ou o devedor, não se olvide, o ingresso nessa relação jurídica se dá independentemente de sua vontade, diante do princípio da inevitabilidade, em que sua situação "é de sujeição, que independe de sua vontade e consiste na impossibilidade de evitar que sobre elas e sobre sua esfera de direitos se exerça a autoridade estatal" (CINTRA; DINAMARCO; GRINOVER, 2012, p. 163).

Do exposto, conclui-se que o devedor se encontra inserido, mesmo contra sua vontade, numa relação jurídica de direito público, na qual possui diversos deveres e ônus, dentre os quais o de lealdade e de cooperação, de modo a desautorizar a ideia de que lhe seja facultado recusar, de forma imotivada, a assunção de um encargo determinado pelo Estado- Juiz no exercício da atividade jurisdicional.

O último argumento - possibilidade de recusa do devedor simplesmente diante da ausência de lei específica, com espeque no art. $5^{\circ}$, II, da $\mathrm{CF} / 88$ - foi invocado nos demais julgados ainda não analisados (Resp 276.886, Resp 214.631, Resp 263.910 e Resp 505.942, além do Resp 161.068), conforme já informado.

O princípio da legalidade estrita representa, na verdade, o argumento principal que hoje fundamenta o entendimento consolidado na Súmula 319 do STJ e será enfrentado adiante em tópico próprio.

Adianta-se, contudo, que o referido entendimento reflete, na verdade, o pensamento em vigor no Estado Liberal, segundo o qual o Estado-Juiz não poderia invadir a esfera de liberdade do indivíduo para obrigá-lo a cumprir determinada prestação contra sua vontade. Assim, vigorava o princípio da tipicidade dos meios executivos, não mais observado em nosso ordenamento (ARENHART; MARINONI, 2008, p 50-51).

Fruto do pensamento liberal que impulsionou a Revolução Francesa, o princípio da legalidade estrita representava a consagração da proteção dos cidadãos em face dos arbítrios perpetrados pelo Estado na pessoa do monarca ao eleger a lei formal como único instrumento legítimo de limitação de suas liberdades e patrimônio. De fato, por conta de sua origem 
democrática, somente a lei poderia estabelecer limitações aos indivíduos, assegurando a liberdade naquilo em que o Parlamento silenciava (NOBRE JÚNIOR, 2009, p. 204).

Portanto, desde sua origem, cuida-se o princípio da legalidade estrita da proteção da autonomia privada dos indivíduos em face da ingerência arbitrária do Estado, elevado à categoria de direito fundamental pela Carta de 1988.

Não obstante, com o advento do novo paradigma constitucional, caracterizado, segundo Barroso (2015, p. 296), pelas "três grandes transformações" operadas pela doutrina pós-positivista em relação à interpretação e aplicação do direito constitucional, notadamente a consagração da força normativa da Constituição, a expansão da jurisdição constitucional e o desenvolvimento de uma nova hermenêutica constitucional, mostra-se necessário promover o redimensionamento do entendimento clássico do princípio da legalidade de modo a conceber os princípios como fontes originárias de obrigações e deveres. É o que será demonstrado a partir dos próximos tópicos.

\section{REDIMENSIONAMENTO DO PRINCÍPIO DA LEGALIDADE: INSERÇÃO DOS PRINCÍPIOS COMO PARÂMETROS DE LEGALIDADE NO CONSTITUCIONALISMO CONTEMPORÂNEO}

A exposição das razões dos precedentes que ensejaram a Súmula 319 do STJ demonstra de forma clara que os Ministros do Superior Tribunal de Justiça deram interpretação bastante restrita ao princípio da legalidade insculpido no art. $5^{\circ}$, II, da CF/88, de modo a concluir pela impossibilidade de imposição do depósito ao devedor por determinação judicial diante da ausência de lei formal nesse sentido.

Referido posicionamento reflete a concepção do Estado Liberal acerca do princípio da legalidade, em que somente a lei emitida pelo Parlamento poderia ser fonte de obrigação. Como se sabe, no Estado Liberal, a lei possuía primazia sobre todas as demais fontes, tendo em vista sua pretensa origem democrática, como destacado por Galindo (2009, p. 177):

O iluminismo oitocentista fez mais do que reavivar o sistema de freios e contrapesos. Ao estipularem a "separação de poderes", não se considerou uma efetiva igualdade entre eles, como por vezes foi preconizada. Ao contrário, foi corrente a ideia de que o parlamento possui primazia em relação aos demais poderes, notadamente por sua legitimidade popular, já que diretamente eleito pela população [...].

A preponderância dessa concepção faz com que a legalidade seja vista como um princípio que institui a lei formal como instrumento de criação do direito. Somente o ato legislativo que cria normas jurídicas gerais cuja origem seja 
parlamentar, seja ato do próprio poder legislativo, é que pode ser consagrador do princípio da legalidade.

O princípio da legalidade, contudo, não pode mais ser concebido de acordo com o pensamento jurídico então vigente no Estado Liberal (ROSA, 2006, p. 414-415).

Mostra-se imperioso, nesse sentido, repensá-lo à luz do atual paradigma do Estado Democrático de Direito, cujo pensamento jurídico vivencia uma nova fase metodológica em que os princípios assumem cogência e constituem, ao lado das espécies normativas emitidas pelo Parlamento, fontes de obrigações jurídicas (NOBRE JÚNIOR, 2009, p. 214-215), cujos valores devem ser concretizados à luz das condicionantes fáticas e jurídicas do caso concreto (ALEXY, 2014, p. 90).

Barroso (2009, p. 144) destaca o papel normativo dos princípios na atualidade do pensamento jurídico, ao lado de sua distinção qualitativa em face das regras, como características marcantes do pós-positivismo.

Para Barroso (2015, p. 276), o pós-positivismo, marco filosófico do constitucionalismo contemporâneo, é a denominação "provisória e genérica” para o pensamento jurídico surgido no período histórico que se sucedeu a Segunda Guerra Mundial, que prestigia “ideais de justiça além da lei e da igualdade material”, além de ser responsável pelo desenvolvimento da teoria dos direitos fundamentais e da reestruturação de uma nova hermenêutica que redefiniu os papéis das regras, princípios e dos valores.

O constitucionalismo contemporâneo, surgido a partir do referido momento histórico, pelo menos no mundo ocidental, é marcado pela ascensão da Constituição ao centro do ordenamento jurídico e pela presença de princípios dotados de alta carga axiológica, com destaque para o princípio da dignidade da pessoa humana e os princípios que compõem os direitos e garantias fundamentais.

No Brasil, esse ideário de ascensão constitucional foi observado somente a partir da promulgação da Carta de 1988, que permitiu a transição, "de maneira bem sucedida", de um regime autoritário e violento para um fundado na ideia de Estado Democrático de Direito, além de ser responsável pelo maior período de estabilidade política em nosso país (BARROSO, 2015, p. 280).

Sarmento (2009, p. 31-32) assim resumiu as características do constitucionalismo contemporâneo, por ele nominado como Neoconstitucionalismo:

Estas mudanças, que se desenvolvem sob a égide da Constituição de 88 , envolvem vários fenômenos diferentes, mas reciprocamente implicados, que 
podem ser assim sintetizados: (a) reconhecimento da força normativa dos princípios e valorização de sua importância no processo de aplicação do Direito; (b) rejeição ao formalismo e recurso mais frequente a métodos ou "estilos" mais abertos de raciocínio jurídico: ponderação, tópica, teorias da argumentação, etc.; (c) constitucionalização do Direito, com a irradiação das normas e valores constitucionais, sobretudo os relacionados aos direitos fundamentais, para todos os ramos do direito; (d) reaproximação entre o Direito e a Moral, com a penetração cada vez maior da Filosofia nos debates jurídicos; e (e) judicialização da política e das relações sociais, com um significativo deslocamento de poder da esfera do Legislativo e do Executivo para o Poder Judiciário.

A doutrina de Cambi (2011, p. 86) também propugna a superação da legalidade restrita, vigente no Estado Liberal, pela nova ótica constitucional, assentada em princípios dotados de normatividade. Em outra passagem, Cambi (2011, p. 88) afirma expressamente que, na atual conjuntura do pensamento jurídico, os princípios constituem fontes primárias do Direito:

Diferentemente da concepção incorporada no modelo positivista de direito (arts. $4^{\circ}$ da LICC [atual Lei de Introdução às Normas do Direito Brasileiro] e 126 do $\mathrm{CPC}$ ), que conferia caráter secundário e subsidiário aos princípios jurídicos, a Constituição se firma como uma ordem objetiva de valores ou um sistema aberto de princípios e de regras.

Os princípios são reconhecidos como pilares axiológicos do sistema jurídico e, conseqüentemente, possuem força normativa imediata. Não exercem apenas a função secundária de preenchimento das lacunas da lei. São fontes primárias de direito, subjacentes às regras, expressando juridicamente os valores e fins de uma sociedade.

Mostra-se defensável, no atual cenário, que os princípios integram o bloco da legalidade, tendo em vista sua posição de proeminência no ordenamento jurídico, em que foram alçados a fonte primária do Direito, capazes, por si próprios, de criar obrigações, já que também ostentam natureza coercitiva, integrando, eles também, o conceito de norma jurídica.

\section{DA FUNDAMENTAÇÃo PRINCIPIOLÓgICA PARA IMPOSIÇÃo DO ENCARGO DE DEPÓSITÁRIO AO ADMINISTRADOR DA EMPRESA EXECUTADA}

Hodiernamente, afigura-se plenamente defensável a ideia de que os princípios podem ser fontes de obrigações jurídicas, a ponto de fundamentar a imposição do encargo de depositário na penhora de percentual de faturamento ao representante legal da empresa executada, independentemente de lei específica nesse sentido. 
Deve restar destacado que, na espécie, não se cuida de legalidade restrita, como ocorre no âmbito do Direito Penal e Tributário, em que há a necessidade de reserva lei formal para a configuração do crime ou da obrigação tributária, respectivamente.

$\mathrm{Na}$ hipótese, cuida-se da possibilidade de aplicação do poder geral de efetivação conferido aos magistrados por força do art. $5^{\circ}, \mathrm{XXXV}$, da $\mathrm{CF} / 88$, para, independentemente de previsão legal expressa, adotar a medida executiva que possua o condão de proporcionar a entrega do exato bem da vida reclamado ou da prestação equivalente, em conformidade com o direito fundamental do credor a uma tutela efetiva e adequada e aos princípios da cooperação e da boa-fé objetiva aplicáveis às relações jurídicas processuais.

Como se sabe, integra o próprio conceito do poder geral de efetivação a possibilidade de o magistrado adotar todas as medidas necessárias à efetivação do direito, independentemente de previsão legal, já que se mostra humanamente impossível ao legislador prever todas as situações fáticas passíveis de tutela jurídica (LEMOS, 2011, p. 150).

Defende-se, portanto, que esse arcabouço principiológico pode constituir a fonte da obrigação de assunção do depósito no instituto em análise, sem falar em ofensa ao princípio da legalidade estrita, em face de seu redimensionamento no constitucionalismo contemporâneo.

Este tópico se ocupa, assim, de demonstrar como os princípios da efetividade da prestação jurisdicional e da atipicidade dos meios executivos, como corolários do non liquet, e os da cooperação, da lealdade e da boa-fé objetiva processual podem funcionar como fontes primárias do dever de o administrador da empresa executada em assumir o depósito na penhora de percentual de faturamento.

\subsection{Tutela efetiva e adequada como direito fundamental e o dever do operador jurídico de interpretar os preceitos legais à luz desse direito fundamental}

No decorrer do processo histórico que levou o Estado da atividade jurisdicional, restou consagrado na Carta Magna de 1988, em seu dispositivo do art. $5^{\circ}$, inciso XXXV, que "a lei não excluirá da apreciação do Poder Judiciário lesão ou ameaça a direito” (BRASIL, 1988), conhecida como a cláusula da vedação do non liquet.

Plasmada como norma fundamental, referido dispositivo constitucional assegura a todos não só apenas o mero ingresso ao Judiciário, mas, precipuamente, em razão do monopólio estatal da atividade jurisdicional, o comprometimento do Estado-juiz em prestar uma tutela 
que seja adequada ao direito pleiteado, bem como a estruturação de um processo que seja dotado de meios que proporcionem efetividade a essa tutela.

Marinoni (2010, p. 139) defende que a consagração do referido princípio é corolário lógico da proibição da resolução do conflito por meio da imposição da força (autotutela), somente permitida entre nós de forma excepcional, a exemplo da legítima defesa e do estado de necessidade. Isso se deve à comprovação histórica de que a utilização da autotutela, meio de resolução de conflito em que não há declaração de direito, mas mera imposição da vontade do mais forte, em nada contribui para a pacificação social.

A prestação jurisdicional garantida pela vedação do non liquet não deve ser compreendida pelo aspecto meramente formal de simples resposta ao direito de promover uma ação. O Estado não pode, sob o pretexto de se desincumbir da nobre missão que lhe conferiu o Poder Constituinte, prestar uma atividade jurisdicional em descompasso com a relação jurídica de direito material deduzida e sem compromisso com os postulados da efetividade e da adequação.

O descumprimento desses postulados possui grande potencial de desestabilização do próprio Estado, como destacado por Arenhart (2003, p. 29):

A crise de legitimidade do processo reflete, dessa forma, a crise de legitimidade do próprio Estado. Se o processo não consegue dar guarida aos direitos concebidos e afirmados pelo Estado, então o Estado não consegue dar a proteção aos interesses que declaradamente aponta como protegidos. E, se assim é, então o Estado mostra sua debilidade e artificialidade, correndo sério risco de ser substituído por ferramenta mais apropriada.

Como expressão do poder estatal, a jurisdição, além de estar comprometida com seu objetivo jurídico, volta-se à realização dos fins almejados pela sociedade, cristalizados na sua Carta Maior. A função jurisdicional, portanto, deve servir, através da aplicação do direito material aos casos em lide, à promoção da paz social, de modo a legitimar a existência do próprio Estado.

Para a consecução desses objetivos, a produção e a aplicação do direito devem se coadunar com os objetivos e princípios vetores do ordenamento jurídico pátrio, plasmados na Constituição. Nesse sentido, lecionam Marinoni e Arenhart (2006, p. 37):

Se o Estado brasileiro está obrigado, segundo a própria Constituição Federal, a construir uma sociedade livre, justa e solidária, a erradicar a pobreza e a marginalização e reduzir as desigualdades sociais e regionais, e ainda a promover o bem de todos, sem preconceitos de origem, raça, sexo, cor, idade e quaisquer outras formas de discriminação (art. $3^{\circ}$ da CF), os fins da jurisdição devem refletir essas idéias. 
Vê-se que, além do seu escopo jurídico, a função jurisdicional busca alcançar um alto grau de pacificação social, espelhado pelos objetivos escolhidos pelo legislador constituinte, os quais restaram veiculados, exemplificadamente, no art. $3^{\circ}$ da Carta Magna de 1988.

Da vedação do non liquet, portanto, surge a necessidade de se dispor de mecanismos jurídicos, seja pela criação de institutos legais (atividade legislativa), seja pela interpretação de regras e princípios do ordenamento (atividade jurisdicional), capazes de dotar a prestação jurisdicional apta à efetivação do direito substancial violado no plano fático (MARINONI, 2010, p. 145-146), sob pena de não se concretizar os fins políticos, jurídicos e sociais da jurisdição, o que poderá acarretar graves danos para a higidez do organismo social.

Alvaro de Oliveira (2010, p. 111) também concebe a inafastabilidade da apreciação pelo Poder Judiciário como corolário da obrigação estatal em prestar uma tutela efetiva, de modo que o processo seja desenvolvido sem "formalismos excessivos" com fito de proporcionar ao vencedor da demanda a entrega do bem jurídico a que faz jus.

Para se alcançar a efetividade imposta pela ordem constitucional, a atividade jurisdicional deve ser desenvolvida tendo em conta a específica relação jurídica de direito material deduzida em juízo. A efetividade da tutela não pode ser dissociada da ideia de adequação, isto é, é preciso que a prestação jurisdicional seja adequada ao direito material deduzido, de modo a possibilitar a entrega ao jurisdicionado do exato bem da vida reclamado, já que vedada, de ordinário, a autotutela.

Assim como sustentam Cintra, Dinamarco e Grinover (2012, p. 43), a relação de necessária implicação entre os princípios da inafastabilidade da apreciação pelo Poder Judiciário e a tutela adequada também é defendida por Nery Junior, para quem, "pelo princípio constitucional do direito de ação, além do direito ao processo justo, todos têm o direito de obter do Poder Judiciário a tutela jurisdicional adequada" (2012, p. 187).

Percebe-se que o ordenamento jurídico brasileiro consagra, como fundamental, o direito a uma tutela adequada e efetiva, o qual deve nortear a atividade do legislador ao traçar as normas processuais. De igual modo, esse direito fundamental à tutela adequada e efetiva deverá ser observado pelos magistrados, que possuem por dever constitucional interpretar as normas processuais e materiais à luz desse direito fundamental.

Acerca da fundamentalidade do direito a uma prestação efetiva e adequada, mostrase pertinente a lição de MARINONI (2010, p. 143): 
Tal direito não poderia deixar de ser pensado como fundamental, uma vez que o direito à prestação jurisdicional efetiva é decorrência da própria existência de direitos e, assim, a contrapartida da proibição da autotutela. O direito à prestação jurisdicional é fundamental para a própria efetividade dos direitos, uma vez que esses últimos, diante de situações de ameaça ou agressão, sempre restam na dependência da sua plena realização. Não é por outro motivo que o direito à prestação jurisdicional efetiva já foi proclamado como o mais importante dos direitos, exatamente por constituir o direito de fazer valer os próprios direitos.

A evolução do sistema jurídico, calcada nos princípios da vedação do non liquet e do direito fundamental a uma tutela efetiva e adequada, levou à substituição do princípio da tipicidade - prevalente no paradigma do Estado legislativo de direito - para o da atipicidade dos meios executivos, hoje positivado no $\$ 5^{\circ}$ do art. 461 do CPC (BRASIL, 1973), que assegura aos magistrados, com o objetivo de proporcionar "a efetivação da tutela específica ou a obtenção do resultado prático equivalente", o poder de, independentemente de previsão legal, "determinar as medidas necessárias" (LEMOS, 2011, p. 149), como, por exemplo, a imposição da assunção do encargo de depositário pelo representante legal da empresa executada.

Outro não é o entendimento de Arenhart e Marinoni (2008, p. 51-52), que destacam a superação do princípio da tipicidade dos meios executivos pelo da atipicidade, mediante concentração de poderes na figura do juiz.

Faz-se necessário, portanto, interpretar o conjunto de normas dos arts. 655, VII, e 655-A, $\S 3^{\circ}$, ambos do CPC, à luz do sistema constitucional que garante aos litigantes em geral uma tutela efetiva e adequada, no sentido de se impor ao representante legal da empresa devedora o dever processual de assumir o encargo do depósito da penhora de percentual de faturamento, a depender das condicionantes fáticas e jurídicas do caso concreto.

$\mathrm{Na}$ grande maioria das vezes, as hipóteses fático-jurídicas que autorizam o deferimento de tal constrição delineiam uma situação limite na execução, em que já restaram frustradas as excussões de quase todos os bens que, de ordinário, despertariam interesse no mercado, passíveis, portanto, de expropriação judicial.

Outorgar ao devedor o direito potestativo de assunção do depósito, nessas situações, significa, por um lado, negar ao credor o direito fundamental a uma tutela efetiva e, de outro, desequilibrar a paridade que deve nortear o processo.

No atual estágio do pensamento jurídico, a alegada ausência de regra legal formal não pode ser invocada para, de forma apriorística, fundamentar a decisão judicial que indefere 
o pedido de imposição ao representante legal da empresa executada do encargo de depositário da penhora de percentual do faturamento.

O constitucionalismo contemporâneo permite ao magistrado, com base no poder geral de efetivação, extraído da cláusula constitucional da inafastabilidade da apreciação pelo Poder Judiciário, impor ao representante legal da empresa executada o dever de assumir o encargo processual do depósito da penhora de percentual de faturamento, sob pena de sua responsabilização pessoal (art. 14, inciso $\mathrm{V}$, parágrafo único, do $\mathrm{CPC}$ ) e de cominação de astreintes à empresa devedora (art. $461, \S 5^{\circ}, \mathrm{CPC}$ ), salvo diante de recusa motivada e devidamente comprovada.

O posicionamento ora exposto, além de prestigiar a concepção do direito fundamental do credor a uma tutela jurisdicional efetiva e adequada, ainda se coaduna com as regras de direito material, segundo a qual as pessoas jurídicas respondem de forma objetiva para com os atos de seus administradores, quando contratados (não-sócios), conforme previsão do 932, III, do Código Civil de 2002 (BRASIL, 2002), ou de forma direta, conforme a ratio do art. 1.015, do mesmo diploma legal (BRASIL, 2002).

O entendimento plasmado na Súmula 319 do STJ, consagrado com base na ideologia superada do Estado Liberal, constitui posicionamento descomprometido com a concepção do direito fundamental a uma tutela jurisdicional efetiva e adequada, que não se coaduna com o paradigma do Estado Democrático de Direito, em que não se admite conduta de indiferença do devedor para com a jurisdição e o processo, a exemplo da recusa imotivada do encargo sob estudo, conforme será analisado na próxima seção deste trabalho.

\subsection{Da imposição do encargo de depositário da penhora de percentual de faturamento ao administrador da empresa executada como corolário dos princípios da cooperação e da boa-fé objetiva processual}

Neste trabalho, defende-se a ideia de que a atividade jurisdicional, desenvolvida através do processo, não pode ser concebida de forma apartada dos objetivos e dos valores plasmados na Constituição Federal de 1988, conformada pelo paradigma do Estado Democrático de Direito.

Nessa linha de raciocínio, o processo deve ser desenvolvido pela doutrina e jurisprudência como instrumento ético de solução de conflitos, regido por princípios de alta 
carga axiológica, a exemplo dos princípios constitucionais da dignidade da pessoa humana (art. $1^{\circ}$, inciso III, CF/88) e da solidariedade (art. $3^{\circ}$, inciso I, CF/88), a exigir do Estado Democrático de Direito a organização de um processo baseado na ideia de cooperação (MITIDIERO, 2011, p. 79-80).

Dentro desse contexto, doutrinadores como Mitidiero (2011, p. 50-51) e Alvaro de Oliveira (2010, p. 22) sustentam a presença de um novo modelo de processo mais adequado ao paradigma do Estado Democrático de Direito, o qual denominam de processo colaborativo ou cooperativo, conforme o marco teórico do formalismo-valorativo.

O processo cooperativo pressupõe, à evidência, o princípio da colaboração (ou da cooperação) como norma cogente e fator de redimensionamento do contraditório, com função de parâmetro de interpretação de normas e fatos, de inibição do abuso do direito processual e de criação de deveres anexos, entre eles, os de esclarecimento, prevenção, consulta e auxílio às partes (MITIDIERO, 2011, p. 83-84).

Esse panorama teórico-jurídico também reserva importante papel ao princípio da boa-fé processual, que passa a ser concebido em seu aspecto objetivo, de igual modo criador de deveres anexos relacionados à lealdade e à confiança, que devem nortear a atividade de interpretação e aplicação do direito processual no caso concreto.

A concepção do processo como instrumento ético de solução de conflitos impõe a efetiva colaboração das partes, de modo que, mais do que faculdade, a demonstração da boafé processual por meio da adoção de atos e condutas processuais, independentemente do elemento subjetivo do ator processual (CRAMER, 2014, p. 627), mostra-se como exigência indeclinável para todos aqueles inseridos na relação jurídica processual instaurada sob o pálio do Estado Democrático de Direito.

A recusa injustificada do representante legal da empresa devedora em assumir o depósito da penhora de percentual do faturamento, portanto, não se coaduna com o princípio da boa-fé objetiva processual e com os deveres de colaboração e lealdade que conformam o processo cooperativo, novo modelo de processo dentro do paradigma do Estado Democrático de Direito, tendo em vista seu inegável conteúdo ético a condicionar a participação colaborativa dos sujeitos da relação processual na comunidade dialética de trabalho, necessária para a validade da tutela a ser prestada pela atividade jurisdicional.

À época dos julgamentos dos precedentes formadores da Súmula 319 do STJ, não se havia consolidado em doutrina e jurisprudência a ideia da objetivação do princípio da boa-fé processual como corolário do processo cooperativo, até mesmo porque, ainda hoje, tais preceitos ainda precisam de maiores aprofundamentos, conforme destacado por Mitidiero 
(2011, p. 107), segundo o qual “o estudo da boa-fé no processo civil na sua perspectiva objetiva é tema que ainda espera desenvolvimento no direito processual civil brasileiro".

O alcance dos referidos princípios deve ser concebido para além das partes do processo (autor e réu, requerido e requerente, exequente e executado), de modo a alcançar não só o órgão judicial, mas todos aqueles que, de qualquer forma, participam da relação jurídica processual, como já assentado pela norma do art. 14 do CPC, que deve ser entendida como a positivação do princípio da boa-fé objetiva processual em nosso ordenamento.

Referido entendimento, inclusive, restou positivado no art. $5^{\circ}$ do novo CPC (BRASIL, 2015), segundo o qual "aquele que de qualquer forma participa do processo deve comportar-se de acordo com a boa-fé".

Igual alcance deve ser conferido à norma principiológica positivada no art. $6^{\circ}$ do novo CPC (BRASIL, 2015), que veicula de forma expressa o princípio da cooperação no ordenamento jurídico processual, ao consignar que todos "os sujeitos do processo devem cooperar entre si para que se obtenha, em tempo razoável, decisão de mérito justa e efetiva".

A postura de indiferença do devedor para com a efetivação da penhora e, consequentemente, para com o processo, mostra-se incompatível com uma atividade jurisdicional que tenha por paradigma um Estado Democrático de Direito, em que o processo deve ser compreendido como instrumento ético de resolução de conflitos, calcado no princípio da colaboração ou cooperação e na ideia da boa-fé processual em seu aspecto objetivo, a exigir das partes comportamentos leais e que prestigiem a confiança legítima.

O Estado-juiz, por seu turno, também não se deve acomodar diante de situações que reclamam sua intervenção, sob pena de esvaziar o comprometimento com os resultados a serem alcançados pela prestação da atividade jurisdicional (DINAMARCO, 2013, p. 41).

Mais do que faculdade, a assunção da condição de depositário da penhora de percentual de faturamento impõe-se à empresa executada, presentada por seus administradores, como dever de colaboração e de atuação leal.

Novamente invoca-se a situação fático-jurídica em que se mostra possível o deferimento da referida imposição judicial ao administrador da empresa executada: existência de título executivo plenamente exigível, seja judicial ou extrajudicial, não vergastado pelo devedor ou atacado por medida processual não dotada de efeito suspensivo - em que não foram reconhecidos, portanto, o fumus boni iuris ou o periculum in mora -, ausência de bens passíveis de penhora que despertem interesse no mercado e impossibilidade do credor em assumir o depósito, bem como inexistência de depositário nos quadros do Poder Judiciário. 
Diante de uma situação limite na execução, a participação leal e cooperativa do devedor se mostra indispensável para a prestação da tutela jurisdicional de forma efetiva e adequada. De fato, a recusa do representante legal da empresa devedora em assumir o depósito da penhora de percentual do faturamento, diante do quadro descrito acima, somente deve ser chancelada pelo Poder Judiciário se vier acompanhada de motivos sérios, plenamente demonstrados por provas idôneas. Somente assim será possível demonstrar que a devedora, presentada em juízo por seus representantes legais, age de acordo com o princípio da boa-fé objetiva processual e, consequentemente, em consonância com o princípio da colaboração.

Caso contrário, resta evidente que uma das partes da relação jurídica processual está a praticar ato atentatório à dignidade da justiça, mediante oposição maliciosa à execução (art. 600, II, CPC), em postura de descaso perante a atividade jurisdicional e de atuação desleal no processo (art. 14, II, CPC), ao se aproveitar de uma situação fático-jurídica para "criar embaraço à efetivação de provimentos jurisdicionais" (art. 14, V, CPC), mediante oposição de "resistência injustificada ao andamento do processo" (art. 17, IV, CPC) (BRASIL, 1973).

O princípio da boa-fé objetiva processual e os deveres de colaboração e lealdade que conformam o processo cooperativo, modelo de processo adequado ao constitucionalismo contemporâneo - em que os princípios assumem força cogente e funcionam como normas primárias de direitos, deveres e obrigações -, podem ser invocados como fundamentos normativos para a imposição ao administrador do encargo em estudo.

\section{DA TEORIA DA PONDERAÇÃo DE ALEXY COMO CONSTRUÇÃo ARGUMENTATIVA RACIONAL DE VALIDAÇÃO DA INTERVENÇÃO JUDICIAL DE IMPOSIÇÃo DO ENCARGo DA PENHORA DE PERCENTUAL DE FATURAMENTO AO ADMINISTRADOR DA EMPRESA EXECUTADA}

Defende-se neste trabalho a possibilidade de o órgão judicial, de acordo com as condicionantes do caso concreto e com base no poder geral de efetivação, corolário da cláusula constitucional da vedação do non liquet (art. 5 $\mathrm{XXXV}, \mathrm{CF} / 88$ ), e nos princípios da cooperação e da boa-fé objetiva processual, impor ao representante legal da empresa devedora o encargo de depositário da penhora de percentual do faturamento, como proposta de superação do entendimento consolidado na Súmula 319 do STJ.

Sustenta-se que a única razão de decidir dos precedentes fundantes do entendimento sumulado que ainda mantém sua força persuasiva é o princípio da legalidade estrita (art. $5^{\circ}$, II, 
$\mathrm{CF} / 88$ ), que possui por objetivo principal proteger a autonomia privada dos particulares contra ingerências arbitrárias do Estado.

Delineia-se, desta forma, uma colisão de princípios constitucionais, ambos positivados como normas fundamentais: de um lado, a autonomia privada protegida pelo princípio da legalidade; de outro, em sentido contrário, o direito fundamental a uma tutela efetiva e adequada, a ser materializada com base no poder geral de efetivação, se preciso for, ambos extraídos da cláusula constitucional da vedação do non liquet.

O presente quadro é categorizado por Alexy como colisão de direitos fundamentais de direitos fundamentais distintos (2015, p. 59), pois, em um polo, há um direito fundamental de origem liberal que protege o devedor contra ingerências, no caso, executivas do Estado- juiz; no outro polo da colisão, afigura-se um direito fundamental de ordem social atribuído ao credor que, apesar de ser exercitável contra o Estado, possui reflexos na autonomia privada do devedor.

Mostra-se imperioso, portanto, realizar uma construção argumentativa que possa resolver esse tipo de colisão de forma racional, tendo em vista a insuficiência do método clássico de interpretação por meio de juízos de subsunção.

Para Alexy, somente uma concepção de direitos fundamentais fundada na teoria dos princípios pode oferecer, de forma satisfatória, respostas racionais ao problema da colisão de princípios, por meio da Teoria da Ponderação (2015, p. 68).

Segundo o referido teórico alemão, existem dois tipos distintos de construções de direitos fundamentais. A primeira, a qual Alexy qualifica de "estreita e rigorosa", denomina de "construção de regras". A segunda, que seria "larga e ampla", é a "construção de princípios". A utilização de uma ou de outra, conforme Alexy, é questão central da problemática da interpretação constitucional em uma ordem "que conhece direitos fundamentais e uma jurisdição constitucional” (2015, p. 105).

A concepção "estreita e rigorosa" preserva a qualidade de normas jurídicas dos direitos fundamentais, bem como sua posição de proeminência no sistema jurídico, mas defende sua aplicação pelo mesmo método das regras (ALEXY, 2015, p. 106), ou seja, através de juízos de subsunção.

A concepção dos direitos fundamentais como "construção de princípios" vai além da função de meramente defender o cidadão, de forma abstrata, das intervenções estatais. 
Para Alexy, esse tipo de construção está "inserida em um quadro mais amplo", cujas bases teóricas foram desenvolvidas na Alemanha pelo Tribunal Constitucional Federal, pela primeira vez, quando do julgamento do caso Lüth, em 1958 (2015, p. 106).

O tribunal de segunda instância de Hamburg condenou Lüth a abster-se de provocar boicotes ao novo filme de Veit Harlan, a quem reputava a pecha de diretor artístico de filmes nazistas, com base no $§ 826$ do código civil alemão, que proíbe a provocação dolosa de danos a outra pessoa (ALEXY, 2015, p. 106).

Em recurso constitucional promovido por Lüth, o tribunal constitucional federal entendeu que o boicote ao novo filme de Harlan encontraria guarida, a princípio, na proteção de liberdade de manifestação prevista no art. 5, alínea 1, da Lei Fundamental. Por seu turno, o art. 5, alínea 2, da Lei Fundamental, contém três cláusulas de limitação a esse direito fundamental, sendo a primeira estabelecida por leis gerais, tal como a disposta no $§ 826$ do código civil alemão (ALEXY, 2015, p. 106-107).

De acordo com a "construção de regras", a demanda seria suficientemente analisada pela realização desses dois juízos de subsunção, quais sejam, a liberdade de manifestação assegurada no art. 5, alínea 1, da Lei Fundamental, na qual estaria albergada a conduta do boicote, pode ser limitada por uma lei geral ( $\$ 826$ do código civil alemão), tal como permite o art. 5, alínea 2, da Lei Fundamental (ALEXY, 2015, p. 107).

O Tribunal Constitucional Federal entendeu por insuficiente a realização de meros juízos de subsunção para dirimir a demanda apresentada por Lüth. Na verdade, a limitação de direitos fundamentais por normas de direito civil conduz sempre a uma ponderação de princípios constitucionais colidentes, em que prevaleceu o princípio da liberdade de opinião (ALEXY, 2015, p. 107).

Conforme Alexy, o caso Lüth serviu para o desenvolvimento de três ideias que conformaram de maneira fundamental o direito constitucional alemão (2015, p. 107).

A primeira é a de que os direitos fundamentais, mais do que disporem, de forma abstrata, de garantias contra o poder estatal, representam, na verdade, uma "ordem objetiva de valores", ou seja, os direitos fundamentais não possuem somente estrutura de regras, mas também de princípios (ALEXY, 2015, p. 107-108).

A segunda ideia é que essa "ordem objetiva de valores" se espraia "para todos os âmbitos do direito", ou seja, vai além da relação entre cidadão e Estado, vinculando também particulares. É o chamado “efeito irradiação" (ALEXY, 2015, p. 108). 
A terceira ideia, por seu turno, resulta como corolário lógico da estrutura dos direitos fundamentais como princípios e valores. Sendo princípios, os direitos fundamentais tendem a colidir. E essa colisão somente poder ser resolvida racionalmente pela ponderação (ALEXY, 2015, p. 108).

O desenvolvimento teórico de Alexy acerca da natureza dos direitos fundamentais como estrutura de regras e princípios ajuda, portanto, a validar a intervenção judicial fundada no poder geral de efetivação sobre a autonomia privada do administrador da empresa executada.

De fato, conforme o referido jusfilósofo alemão:

Direitos fundamentais, como princípios, são mandamentos de otimização. Como mandamento de otimização, princípios são normas que ordenam que algo seja realizado em medida tão alta quanto possível relativamente às possibilidades fáticas e jurídicas (ALEXY, 2015, p. 110).

Segundo Alexy, a exemplo do que restou afirmado pelo Tribunal Constitucional Federal alemão, há uma estreita conexão entre a natureza principiológica dos direitos fundamentais e as máximas parciais do princípio da proporcionalidade, quais sejam, adequação, necessidade e proporcionalidade em sentido restrito. Assim, as condicionantes fáticas estariam relacionadas com as máximas parciais da adequação e da necessidade; por seu turno, a máxima parcial da proporcionalidade em sentido restrito estaria relacionada às condicionantes jurídicas, para as quais seria necessário realizar a ponderação $(2014$, p. 116117).

Defende Alexy, portanto, que, para que se possa justificar uma intervenção em um direito fundamental, faz-se necessário realizar uma ponderação, que corresponde ao terceiro princípio parcial do princípio da proporcionalidade (2015, p. 67).

Antes de se realizar a ponderação, contudo, é preciso verificar se a medida proposta atende aos princípios ou máximas parciais do princípio da proporcionalidade ligadas às condicionantes fáticas, quais sejam, adequação e idoneidade.

Ao se retornar ao caso ora em estudo, verifica-se que a primeira máxima parcial resta plenamente atendida, pois o meio empregado pela medida de intervenção judicial se presta à solução do problema, sendo adequado à concretização da penhora de percentual de faturamento. De fato, o administrador da empresa executada é aquele que possui atribuições legais e contratuais para desempenhar atividades inerentes à administração da empresa devedora, tal como a de determinar o depósito judicial dos valores fixados na penhora de percentual do faturamento. 
A nomeação de um terceiro para exercer o encargo, por seu turno, é medida que pode não se mostrar idônea, pois é altamente provável o surgimento de óbices práticos quanto ao acesso do administrador à contabilidade da empresa devedora, bem como de discrepâncias entre os dados apresentados pelo auxiliar do juízo e pelo devedor.

Por seu turno, na grande maioria das situações, também haverá o atendimento ao princípio parcial da necessidade, pois é medida menos gravosa ao devedor.

A nomeação de um terceiro para administrar a penhora de percentual de faturamento, além de ser de difícil aplicação na prática, diante da escassez de profissionais dispostos a assumir tal encargo e da carência de depositários judiciais nos quadros do Poder Judiciário, não se dá de forma gratuita. E esse custo econômico será suportado pelo devedor.

Além de suportar o ônus econômico pela nomeação do terceiro depositário, a empresa devedora teria que admitir a ingerência de pessoa alheia ao seu quadro societário no cotidiano de sua atividade empresarial, razão pela qual a tese que se apresenta ainda se escora no art. 620 do CPC em vigor (BRASIL, 1973), que consagra o princípio da execução menos gravosa ao devedor, mantido no art. 805 do novo CPC (BRASIL, 2015).

A medida de intervenção judicial de imposição do encargo de depositário ao administrador da empresa executada também atende ao último princípio parcial da proporcionalidade em sentido restrito, correspondente à ponderação em sua estruturação mais simples (ALEXY, 2015, p. 111).

Segundo Alexy, a lei da ponderação pode ser estruturada em três passos. Em um primeiro momento se atribui peso ao não cumprimento ou prejuízo de um dos princípios colidentes, conforme uma escala triádica (leve, médio ou grave); no segundo passo, atribui-se peso à importância do outro princípio em sentido contrário, conforme a mesma escala triádica; por fim, realiza-se a ponderação estritamente dita, por meio da demonstração de que a intervenção em um direito fundamental se justifica pela importância atribuída ao outro em sentido contrário, resumido pela seguinte fórmula: "quanto mais alto é o grau do não cumprimento ou prejuízo de um princípio, tanto maior deve ser a importância do cumprimento do outro" (2015, p. 133).

Conforme a lei de ponderação proposta por Alexy, pode-se atribuir grau leve, no máximo de ordem mediana, à intervenção judicial que impõe, episodicamente, a ampliação das atribuições ordinárias do administrador da empresa executada.

De fato, seja pela imposição legal do art. 1.015 do Código Civil em vigor (BRASIL, 2002), seja por previsão contratual, o administrador, sócio ou não, é o responsável pela administração da atividade social desenvolvida pela devedora. A assunção desse encargo, 
portanto, não traria maiores transtornos ao representante legal, que teria apenas a responsabilidade de promover o depósito em juízo de parte do faturamento da empresa que ele próprio administra.

Acrescente-se a impossibilidade de prisão civil do depositário nessa situação e se justificará a atribuição do grau leve, no máximo de ordem mediana, a essa intervenção no direito fundamental do administrador da empresa devedora.

No sentido contrário, afigura-se como grave, no mínimo de grau médio, o não cumprimento do direito fundamental à tutela efetiva e adequada, diante da potência de frustração da execução.

A hipótese fático-jurídica que autoriza o deferimento da penhora de percentual de faturamento revela uma situação limite na execução. De fato, em doutrina e jurisprudência, resta assente o entendimento de que esse tipo de constrição somente tem lugar em situações excepcionais, quando já restaram frustradas outras modalidades mais efetivas de constrição, a exemplo da penhora de pecúnia ou de bens imóveis.

Não se deve olvidar que, na gradação legal, tanto no atual como no novo CPC, a penhora de percentual de faturamento ocupa a posição de preferência somente em relação a bens e direitos que dificilmente despertam interesse no mercado. Ademais, a propriedade de alguns desses bens (pedras e metais preciosos, títulos e valores mobiliários com cotação em mercado) por empresas sujeitas a uma execução é fato raro, sem falar a complexidade de suas avaliações (outros direitos, como marcas e patentes, por exemplo), fatores que, quando somados, tornam bastante factível a frustração da execução.

Logo se conclui que, em uma situação fático-jurídica que autoriza o deferimento da penhora, não restaram muitas alternativas ao credor que não seja a efetivação dessa constrição. Assim, respaldados pela Súmula 319 do STJ e cônscios de que, na grande maioria das vezes, o credor não possui condições de assumir o encargo, como também da ausência de depositários judiciais nos quadros do Poder Judiciário, muitos representantes legais de empresas executadas recusam a assunção do múnus de maneira injustificada, conduta essa que possui alto grau de potência de ocasionar a frustração da execução.

A recusa injustificada do encargo não mais deve ser prestigiada pelo Poder Judiciário, sob pena de negativa da própria atividade jurisdicional, que não será efetiva, nem adequada.

É preciso destacar a importância do direito fundamental a uma tutela efetiva e adequada, de modo a justificar a atribuição do grau grave, no mínimo de ordem mediana, ao 
não cumprimento desse direito fundamental na hipótese ora examinada. De fato, segundo Alexy, "se algumas normas da constituição não são levadas a sério, é difícil fundamentar por que outras normas também então devem ser levadas a sério se isso uma vez causa dificuldades. Ameaça a dissolução da constituição" (ALEXY, 2015, p. 63).

Justifica-se, portanto, por meio de um discurso racional, a intervenção judicial, em grau leve (no máximo de ordem mediana), no direito fundamental do sócio-administrador, dada a gravidade das razões que sustentam essa intervenção, diante da alta probabilidade de frustração da execução, na linha do pensamento de Alexy:

\footnotetext{
Uma intervenção em um direito fundamental é desproporcional quando ela não é justificada por uma outra intervenção hipotética, pelo menos, igualmente intensiva, em um outro princípio - contido na constituição ou por ela admitido como fundamento de intervenção - a qual, pela omissão da primeira intervenção, iria tornar-se real (2015, p. 113).
}

Na hipótese ora proposta, demonstrou-se que houve, no mínimo, equivalência de peso entre o grau de intervenção em um direito fundamental (leve, ou no máximo de ordem mediana) e o não cumprimento do outro direito fundamental colidente (grave, no mínimo de ordem mediana), de modo que a medida proposta se mostra proporcional.

E sendo proporcional, resta satisfeita a pretensão de correção quanto ao conteúdo respeito aos direitos fundamentais (ALEXY, 2015, p. 33) -, ora justificada diante do contexto fático-jurídico apresentado, pretensão essa que deve ser sempre buscada por uma teoria discursiva que se pretende comprometida com a ideia de legitimidade do Direito.

\section{CONCLUSÕES}

Neste trabalho, defendeu-se a validade da decisão judicial, com base na Teoria da Ponderação em Alexy, que impõe ao administrador da empresa devedora, seja sócio ou não, o dever de assumir o encargo de depositário da penhora de percentual do faturamento, determinada nos termos dos arts. 655, VII, e 655-A, $\S 3^{\circ}$, ambos do CPC.

Para isso, pugnou-se pela superação do entendimento plasmado na Súmula 319 do STJ, que reflete o pensamento do Estado Liberal de não ingerência na esfera individual do devedor, por meio do redimensionamento do princípio da legalidade estrita perante o atual constitucionalismo, de modo a incluir princípios no bloco da legalidade.

Restou evidenciado que a recusa vazia de assunção do encargo, com base na inexistência de lei formal específica nesse sentido, possui grande potencial de frustrar a execução, conduta 
essa que entra em rota de colisão com o direito fundamental a uma tutela adequada e efetiva, extraído do art. $5^{\circ}, \mathrm{XXXV}$, da CF/88.

Como forma de validar de forma racional a decisão judicial que se depara com a situação de colisão entre o direito fundamental da autonomia da vontade do particular, protegida pelo princípio da legalidade estrita, e, em sentido, contrário, o direito fundamental à tutela efetiva e adequada, decorrente da cláusula constitucional da vedação do non liquet, valeuse da Teoria da Ponderação de Alexy.

Demonstrou-se, nesse sentido, que a medida proposta acima é adequada, pois viabiliza a concretização fática da penhora em comento; também é menos gravosa, vez que evita a colocação de terceiro estranho à sociedade a frente de sua administração, com custo econômico a ser suportado pela empresa devedora; e atende ao último princípio parcial, correspondente à ponderação em sua estruturação mais simples.

De fato, pode-se atribuir grau leve na intervenção judicial que impõe, episodicamente, a ampliação das atribuições ordinárias do sócio-administrador da empresa executada. No sentido contrário, afigura-se como grave, no mínimo de ordem mediana, o não cumprimento do direito fundamental à tutela efetiva e adequada, diante da potência de frustração da execução.

Justifica-se, portanto, por meio de um discurso racional, a intervenção judicial (em grau leve) no direito fundamental do sócio-administrador, dada a gravidade das razões que sustentam essa intervenção, sem prescindir da pretensão de correção quanto ao respeito aos direitos fundamentais, ideia cara ao modelo do constitucionalismo contemporâneo.

\section{REFERÊNCIAS}

ALEXY, Robert. Constitucionalismo discursivo. 4. ed. Porto Alegre, Livraria do Advogado, 2015.

Teoria dos direitos fundamentais. 2. ed. São Paulo: Malheiros, 2014.

ALVARO DE OLIVEIRA, Carlos Alberto. Do formalismo no processo civil: proposta de um Formalismo-Valorativo. 4. ed. São Paulo: Saraiva, 2010.

ARENHART, Sérgio Cruz. Perfis da tutela inibitória coletiva. São Paulo: Revista dos Tribunais, 2003. 
ARENHART, Sérgio Cruz; MARINONI, Luiz Guilherme. Manual do processo de conhecimento. 5. ed. São Paulo: Revista dos Tribunais, 2006.

Curso de processo civil. 2. ed. São Paulo: Revista dos Tribunais, 2008, v. 3.

BARROSO, Luís Roberto. Curso de direito constitucional contemporâneo: os conceitos fundamentais e a construção do novo modelo. 5. ed. São Paulo: Saraiva, 2015.

Novos paradigmas e categorias da interpretação constitucional. In: CAMARGO, Marcelo Novelino (org.). Leituras complementares de direito constitucional. Teoria da Constituição. Salvador: JusPodivm, 2009.

BRAGA, Paula Sarno. et al. Curso de direito processual civil. Salvador: JusPodivm, 2009, v. 5 .

BRASIL. Constituição da República Federativa do Brasil de 1988. Diário Oficial [da] República Federativa do Brasil, Poder Constituinte, Brasília, DF, 5 out. 1988. Disponível em: $\quad$ http://www.planalto.gov.br/ccivil_03/Constituicao/ConstituicaoCompilado.htm>. Acesso em: 13 jul. 2015.

Decreto $n^{\circ}$ 678, de 6 de novembro de 1992. Promulga a Convenção Americana sobre Direitos Humanos (Pacto de São José da Costa Rica), de 22 de novembro de 1969. Diário Oficial [da] República Federativa do Brasil, Poder Executivo, Brasília, DF, 9 mar. 1992. Disponível em: <http://www.planalto.gov.br/ccivil_03/decreto/D0678.htm>. Acesso em: 13 jul. 2015.

Lei $\mathrm{n}^{\circ}$ 5.869, de 11 de janeiro de 1973. Código de Processo Civil. Diário Oficial [da] República Federativa do Brasil, Poder Legislativo, Brasília, DF, 17 jan. 1973. Disponível em: <http://www.planalto.gov.br/ccivil_03/leis/L5869compilada.htm>. Acesso em: 13 jul. 2015 .

Lei $\mathrm{n}^{\mathrm{o}}$ 10.406, de 10 de janeiro de 2002. Código Civil. Diário Oficial [da] República Federativa do Brasil, Poder Legislativo, Brasília, DF, 11 jan. 2002. Disponível em: <http://www.planalto.gov.br/ccivil_03/leis/2002/L10406.htm\#art2044>. Acesso em 14 jul. 2015 .

Lei ${ }^{\circ} 11.382$, de 6 de dezembro de 2006. Altera dispositivos da Lei $n^{0} 5.869$, de 11 de janeiro de 1973 - Código de Processo Civil, relativos ao processo de execução e a outros assuntos. Diário Oficial [da] República Federativa do Brasil, Poder Legislativo, Brasília, DF, 7 dez. 2006. Disponível em: <http://www.planalto.gov.br/ccivil_03/_ato20042006/2006/lei/l11382.htm>. Acesso em 14 jul. 2015.

Lei $\mathrm{n}^{\mathrm{o}}$ 13.105, de 16 de março de 2015. Código de Processo Civil. Diário Oficial [da] República Federativa do Brasil, Poder Legislativo, Brasília, DF, 17 mar. 2015. Disponível em: <http://www.planalto.gov.br/ccivil_03/_Ato20152018/2015/Lei/L13105.htm\#art1045>. Acesso em: 13 jul. 2015.

Superior Tribunal de Justiça. Agravo Regimental no Agravo de Instrumento $\mathrm{n}^{\circ}$ 199.378. Agravante: Banco do Brasil S/A. Agravado: Agnelo Malaquias da Costa. Relator: Ministro Nilson Naves. Brasília, DF, DJ 04 out. 1999a. Disponível em: 
<https://ww2.stj.jus.br/processo/jsp/ita/abreDocumento.jsp?num_registro=199800580360\&dt _publicacao=04-10-1999\&cod_tipo_documento=>. Acesso em 15 jul. 2015.

Superior Tribunal de Justiça. Agravo Regimental no Recurso Especial no 1.313.904. Agravante: Randi Indústrias Texteis Ltda. Agravado: Fazenda do Estado de São Paulo. Relator: Ministro Humberto Matins. Brasília, DF, DJe 21 maio 2012a. Disponível em: $<$ https://ww2.stj.jus.br/processo/jsp/ita/abreDocumento.jsp?num_registro=199800580360\&dt _publicacao=04-10-1999\&cod_tipo_documento=>. Acesso em 14 jul. 2015.

Superior Tribunal de Justiça. Agravo Regimental no Recurso Especial nº 1.320.996. Agravante: Tevah Vestuário Masculino Ltda. Agravado: Fazenda Nacional. Relator: Ministro Castro Meira. Brasília, DF, DJe 11 set. 2012b. Disponível em: <https://ww2.stj.jus.br/processo/jsp/ita/abreDocumento.jsp?num_registro=199800580360\&dt _publicacao=04-10-1999\&cod_tipo_documento=>. Acesso em 14 jul. 2015.

Superior Tribunal de Justiça. Habeas Corpus $n^{\circ}$ 20.789. Impetrante: Luiz Sérgio Marrano e outro. Impetrado: Sexta Câmara de Direito Público do Tribunal de Justiça do Estado de São Paulo. Relator: Ministro Francisco Falcão. Brasília, DF, DJ 17 maio 2004a. Disponível

em: <https://ww2.stj.jus.br/revistaeletronica/Abre_Documento.asp?sSeq=462487\&sReg=2002001 $38493 \&$ sData=20040517\&formato=PDF $>$. Acesso em 15 jul. 2015.

Superior Tribunal de Justiça. Habeas Corpus $\mathrm{n}^{\circ}$ 28.152. Impetrante: Ailton Luciano dos Santos. Impetrada: Primeira Turma Cível do Tribunal de Justiça do Estado do Mato Grosso do Sul. Relator: Ministro Antônio de Pádua Ribeiro. Brasília, DF, DJ 12 ago. 2003a. Disponível

em: $<$ https://ww2.stj.jus.br/revistaeletronica/Abre_Documento.asp?sSeq=415581\&sReg=2003006

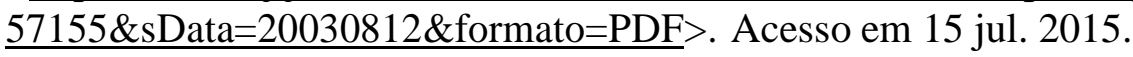

Superior Tribunal de Justiça. Habeas Corpus n ${ }^{\circ}$ 31.733. Impetrante: Adriane Marangoni. Impetrado: Tribunal de Justiça do Estado de São Paulo. Relator: Ministro Francisco Peçanha Martins. Brasília, DF, DJ 26 abr. 2004b. Disponível em: <https://ww2.stj.jus.br/revistaeletronica/Abre_Documento.asp?sSeq=459147\&sReg=2003020 57401\&sData=20040426\&formato=PDF>. Acesso em 15 jul. 2015.

Superior Tribunal de Justiça. Habeas Corpus $\mathrm{n}^{\circ}$ 34.229. Impetrante: Emerson Tadao Asato. Impetrado: Sétima Câmara de Direito Privado do Tribunal de Justiça do Estado de São Paulo. Relator: Ministro Humberto Gomes de Barros. Brasília, DF, DJ 06 set. 2004c. Disponível em:

<https://ww2.stj.jus.br/revistaeletronica/Abre_Documento.asp?sSeq=491632\&sReg=2004003 32914\&sData=20040906\&formato=PDF>. Acesso em 15 jul. 2015.

Superior Tribunal de Justiça. Habeas Corpus $n^{\circ}$ 54.575. Impetrante: Antônio Carlos Mariz de Oliveira e outros. Impetrado: Tribunal de Justiça do Estado de São Paulo. Relator: Ministro Felix Fischer. Brasília, DF, DJ, 19 nov. 2007. Disponível em: < https://ww2.stj.jus.br/revistaeletronica/Abre_Documento.asp?sSeq=720298\&sReg=20060032 $3645 \&$ sData $=20071119 \&$ formato=PDF $>$. Acesso em 18 jul. 2015. 
Superior Tribunal de Justiça. Habeas Corpus $\mathrm{n}^{\circ}$ 145.747. Impetrante: Gustavo Sipolatti e outro. Impetrado: Tribunal Regional Federal da $2^{\text {a }}$ Região. Relator: Ministro Felix Fischer. Brasília, DF, DJe 22 mar. 2010a. Disponível em: <https://ww2.stj.jus.br/revistaeletronica/Abre_Documento.asp?sSeq=932531\&sReg=2009016 $72309 \&$ sData=20100322\&formato=PDF $>$. Acesso em 18 jul. 2015.

Superior Tribunal de Justiça. Recurso Especial no 161.068. Recorrente: Fazenda do Estado de São Paulo. Recorrido: Spig S/A. Relator: Ministro Adhemar Maciel. Brasília, DF, DJ 19 out. $1998 . \quad$ Disponível em: https://ww2.stj.jus.br/processo/jsp/ita/abreDocumento.jsp?num_registro=199700934420\&dt_ publicacao=19-10-1998\&cod_tipo_documento=>. Acesso em 15 jul. 2015.

Superior Tribunal de Justiça. Recurso Especial no 214.631. Recorrente: Spig S/A. Recorrido: Fazenda do Estado de São Paulo. Relator: Ministro Garcia Vieira. Brasília, DF, DJ 20 set. 1999b. Disponível em: < https://ww2.stj.jus.br/processo/jsp/ita/abreDocumento.jsp?num_registro=199900427572\&dt_ publicacao=20-09-1999\&cod_tipo_documento=>. Acesso em 15 jul. 2015.

Superior Tribunal de Justiça. Recurso Especial $\mathrm{n}^{\mathbf{0}}$ 263.910. Recorrente: Merak Indústria Mecânica Ltda. Recorrido: Fazenda do Estado de São Paulo. Relator: Ministro Castro Meira. Brasília, DF, DJ 16 nov. 2004d. Disponível em: <https://ww2.stj.jus.br/revistaeletronica/Abre_Documento.asp?sSeq=503133\&sReg=2000006 10992\&sData=20041116\&formato=PDF $>$. Acesso em 15 jul. 2015.

Superior Tribunal de Justiça. Recurso Especial $n^{\circ}$ 276.886. Recorrente: Manap Manufatura Nacional de Plásticos S/A. Recorrido: Fazenda do Estado de São Paulo. Relator: Ministro José Delgado. Brasília, DF, DJ 05 fev. 2001. Disponível em: <https://ww2.stj.jus.br/websecstj/cgi/revista/REJ.cgi/IMGD?seq=265195\&nreg=2000009188 $73 \& \mathrm{dt}=20010205 \&$ formato=PDF $>$. Acesso em 15 jul. 2015.

Superior Tribunal de Justiça. Recurso Especial $\mathrm{n}^{\circ}$ 505.942. Recorrente: Transportadora Tegon Valenti S/A. Recorrido: Fazenda Pública do Estado do Paraná. Relatora: Ministra Denise Arruda. Brasília, DF, DJ 06 jun. 2005a. Disponível em: <https://ww2.stj.jus.br/revistaeletronica/Abre_Documento.asp?sSeq $=563727 \&$ sReg=2003000 $50718 \&$ sData $=20050829 \&$ formato=PDF $>$. Acesso em 15 jul. 2015.

Superior Tribunal de Justiça. Recurso Ordinário em Habeas Corpus $\mathrm{n}^{\mathrm{o}}$ 14.647. Recorrente: Fátima Maria de Souza Nogueira. Recorrido: Tribunal Regional Federal da $3^{\mathrm{a}}$ Região. Relatora: Ministra Eliana Calmon. Brasília, DF, DJ 01 set. 2003b. Disponível em: <https://ww2.stj.jus.br/revistaeletronica/Abre_Documento.asp?sSeq=417347\&sReg=2003011 53322\&sData=20030901\&formato=PDF $>$. Acesso em 15 jul. 2015.

Superior Tribunal de Justiça. Recurso Ordinário em Habeas Corpus $\mathrm{n}^{\circ} 15.891$. Recorrente: Darci Batista. Recorrido: Tribunal Regional Federal da $3^{a}$ Região. Relator: Ministro Luiz Fux. Brasília, DF, DJ 23 ago. 2004e. Disponível em: <https://ww2.stj.jus.br/revistaeletronica/Abre_Documento.asp?sSeq=483570\&sReg=2004004 $37745 \&$ sData=20040823\&formato=PDF $>$. Acesso em 15 jul. 2015.

Superior Tribunal de Justiça. Súmula no 319. O encargo de depositário de bens penhorados pode ser expressamente recusado. Brasília, DF, DJ 18 out. 2005b. Disponível em: <http://www.stj.jus.br/SCON/sumulas/toc.jsp?tipo_visualizacao=null\&livre=319\&b=SUMU \&thesaurus=JURIDICO $>$. Acesso em 15 jul. 2015. 
Superior Tribunal de Justiça. Súmula no 419. Descabe a prisão civil do depositário
infiel. Brasília, DF, DJe 11 mar. 2010. Disponível em: <http://www.stj.jus.br/SCON/pesquisar.jsp>. Acesso em 17 jul. 2015.

Supremo Tribunal Federal. Habeas-corpus $\mathrm{n}^{\circ}$ 90.450. Impetrante: Demétrius Nicolaos Nikolaidis. Impetrado: Presidente do Superior Tribunal de Justiça. Relator: Ministro Celso de Mello. Brasília, DF, DJe-025 06 fev. 2009a. Disponível em: $<$ http://redir.stf.jus.br/paginadorpub/paginador.jsp?docTP=AC\&docID=573711 >. Acesso em 16 jul. 2015.

Supremo Tribunal Federal. Súmula Vinculante $\mathbf{n}^{\mathbf{0}}$ 25. É ilícita a prisão civil de depositário infiel, qualquer que seja a modalidade do depósito. Brasília, DF, DJe-238 23 dez. $2009 b$. Disponível em: <http://www.stf.jus.br/arquivo/cms/jurisprudenciaSumulaVinculante/anexo/PSV_31.pdf >. Acesso em 17 jul. 2015.

CAMBI, Eduardo. Neconstitucionalismo e neoprocessualismo: direitos fundamentais, políticas públicas e protagonismo judiciário. 2. ed. São Paulo: Revista dos Tribunais, 2011.

CINTRA, Antônio Carlos de. DINAMARCO, Cândido Rangel. GRINOVER, Ada Pellegrini. Teoria geral do processo. 28. ed. São Paulo: Malheiros, 2012.

CRAMER, Ronaldo. O princípio da boa-fé objetiva no projeto do novo CPC. In: DANTAS, Bruno, et al. (orgs.). Novas tendências do processo civil: estudos sobre o projeto do novo código de processo civil. Salvador: JusPodivm, 2014, v. III.

GALINDO, Bruno. Princípio da legalidade oblíqua e súmula vinculante: a atuação legislativa da jurisdição constitucional nos 20 anos da Constituição de 1988. In: BRANDÃO, Cláudio. CAVALCANTI, Francisco. ADEODATO, João Maurício. (Coord.). Princípio da legalidade: da dogmática jurídica à teoria do direito. Rio de Janeiro: Forense, 2009, p. 177.

DINAMARCO, Cândido Rangel. A instrumentalidade do processo. 15. ed. São Paulo: Malheiros, 2013.

LEMOS, Jonathan Iovane de. O processo de execução e a influência cultural em sua delimitação: das medidas sub-rogatórias e das técnicas executivas pré-determinadas à atipicidade dos meios. Revista de Processo, São Paulo, v. 200, p. 125-157, out. 2011.

MARINONI, Luiz Guilherme. Técnica processual e tutela dos direitos. 3. ed. São Paulo: Revista dos Tribunais, 2010.

MITIDIERO, Daniel. Colaboração no processo civil: pressupostos sociais, lógicos e éticos. 2. ed. São Paulo: Revista dos Tribunais, 2011.

NERY JUNIOR, Nelson. Princípios do processo na Constituição Federal: processo civil, penal e administrativo. 11. ed. São Paulo: Revista dos Tribunais, 2012. 
NOBRE JÚNIOR, Edílson Pereira. Administração pública, legalidade e pós-positivismo. In: BRANDÃO, Cláudio. CAVALCANTI, Francisco. ADEODATO, João Maurício. (coordenadores). Princípio da legalidade: da dogmática jurídica à teoria do direito. Rio de Janeiro: Forense, 2009.

ROSA. André Vicente Pires. Las omisiones legislativas y su control constitucional. Rio de Janeiro: Renovar, 2006.

SARMENTO, Daniel. O neoconstitucionalismo no Brasil: riscos e possibilidades. In: CAMARGO, Marcelo Novelino (Org.). Leituras complementares de direito constitucional: teoria da constituição. Salvador: JusPodivm, 2009. 